\title{
DISEASES OF THE NASAL CAVITY IN THE DOG. AETIOLOGY, SYMPTOMATOLOGY, DIAGNOSTICS.
}

\author{
Z. KNOTEK, T. FICHTEL, P. KOHOUT, J. BENÁK \\ Small Animal Clinic, Faculty of Veterinary Medicine, University of Veterinary \\ and Pharmaceutical Sciences, Brno, Czech Republic
}

Received April 4, 2000

Accepted February 7, 2001

\begin{abstract}
Knotek Z., T. Fichtel, P. Kohout, J. Benák: Diseases of the Nasal Cavity in the Dog. Aetiology, Symptomatology, Diagnostics. Acta Vet. Brno 2001, 70: 73-82.

A system of intravital differential diagnostics of diseases of the nasal cavity was verified in 40 dogs. Patients were induced to analgosedation by a combination of medetomidine and butorphanol for the purpose of taking radiographs of the nasal cavity. In order to obtain samples for cytology and histological examination, patients were induced by propofol and then kept under inhalation anaesthesia using halothane or isoflurane. A rigid endoscope (Hopkins, diameter $2.7 \mathrm{~mm}, 18 \mathrm{~cm}$ ) was used to examine the nasal cavity thoroughly. Tissue specimens from areas of damaged mucosa and inner structures of the nasal cavity were under endoscopic guidance sampled using bioptic forceps. One part of samples was used to make impression smears for cytological evaluation; the other part for histological processing. In patients suffering from chronic infectious rhinitis and neoplasia we found in both groups marked and advanced changes in the internal architecture of the nasal cavity (aggressive lesions). In several cases of mycotic rhinitis caused by fungi of the Aspergillus genus we observed typical pale plaques. Foreign bodies, mainly such as awns and parts of grass spikes, were mechanically removed using endoscopic forceps. Granulomas had a tendency to profuse bleeding. There were no serious cases of severe bleeding during examination. Results of bacteriological cultivation were compared to those obtained by cytology and histology. In 40 of these combined examinations there were in 16 cases $(40 \%)$ confirmed bacterial rhinitis cases without the presence of fungi and changes typical of neoplastic processes. Staphylococcus intermedius, Streptococcus canis and Pasteurella canis were cultured most frequently. Other bacterial agents were diagnosed only exceptionally. Mycotic infections were found in 7 cases of chronic rhinitis (i.e., 17.5\%). The genus Aspergillus amounted to more than $85 \%$ of mycotic agent detection. Fungi occurred as a complication to a foreign body in the nasal cavity in two cases. There were no cases of allergic rhinitis in the group of patients studied. Malignant neoplasia were prevailing $(77.8 \%)$. Osteosarcoma, lymphosarcoma and adenocarcinoma were frequent neoplasia found in the nasal cavity of the dog.
\end{abstract}

Rhinoscopy, bacterial and mycotic rhinitis, nasal cavity neoplasia

There are primary or secondary rhinitis cases in the dog and cat. Important causes of chronic rhinitis are foreign bodies and diseases of teeth such as periodontitis, periapical granuloma and oronasal fistulas (Forbes Lent and Hawkins 1992; Gaskell and Gaskell 1997; Marretta 1992; Norsworthy 1995a; Wolf 1992). Food allergies are also accompanied by chronic rhinitis. From viral infections in the dog we may consider distemper and kennel cough agents.

Pseudomonas aeruginosa, Pasteurella multocida and Staphylococcus sp. (present even on the mucosa of respiratory tract of animals without clinical disease; Cani atti et al. 1998a; Forbes Lent and Hawkins 1992) are mentioned most frequently from the possible bacterial agents causing rhinitis in the dog and cat. Mycotic rhinitis cases in the dog are caused by Aspergillus sp. (Aspergillus fumigatus, rarely A. niger, A. nidulans, A. flavus. Penicillium sp.). There is a predisposition of dolichocephalic breeds (retrievers, German Shepherd Dog), while brachycephalic breeds are supposed to be affected less frequently by

Address for correspondence:

Doc. MVDr. Zdeněk Knotek, CSc.

Faculty of Veterinary Medicine

cutical Sciences

Palackého 1-3,612 42 Brno, Czech Republic
Phone: +420541562382

Fax: +420 541562382

http://www.vfu.cz/acta-vet/actavet.htm 
mycotic rhinitis. As far as cats are concerned, the first place is occupied by Cryptococcus neoformans, less frequently Aspergillus sp., Histoplasma capsulatum and Blastomyces dermatitidis. Alternaria alata, Exophiala spinifera, Trichosporon sp., Blastomyces dermatidis, Histoplasma capsulatum and Prototheca wickerhamii (Caniatti et al. 1998ab; Norsw orthy 1995a; Wolf 1992) belong to less frequent causative agents of rhinitis in the dog and cat.

As far as intranasal parasites are concerned, Pneumonyssus caninum, rarely Toxoplasma gondii and Capillaria (Gallow ay et al. 1997), are encountered. There were described cases of chronic rhinitis in the dog caused by Rhinosporidium seeberi (Coccidium seeberi, Rhinosporidium kinealyi, R. equi, Caniatti et al. 1998b) on the continent of America and in the south of Europe. Neoplasia in the nasal cavity of the dog and cat amount only to about 0.3 to $2.4 \%$ of all neoplastic diseases (60\% out of this number are represented by carcinoma, adenocarcinoma, and squamous carcinoma). Fibrosarcoma, chondrosarcoma and osteosarcoma cases are mentioned as less frequent. In older cats we may expect squamous carcinoma, adenocarcinoma, carcinoma and lymphosarcoma, while the rest is represented by other types of tumours (neuroblastoma, fibrosarcoma, chondrosarcoma and chondroma). Primary neoplasia in the nasal cavity of cats are rather rare and amount to about $1 \%$ of tumours in cats (O'Brien et al. 1996; Ogilvie and LaRue 1992; Théon et al. 1995; Théon et al. 1996). Nasal polyps affect mainly ethmoturbinates. They include the fibrous as well as the vascular tissue. Polyps in the nasal cavity in cats are termed as fibrous dysplasia, ossified fibroma, inflammatory polyps, and bony aneurysmal cysts. They are most probably a sequel to chronic inflammatory processes in upper respiratory tract of infectious aetiology. Chronic rhinitis cases in relation to diseases of teeth are caused by periodontitis and endodontitis, less frequently osteomyelitis, intranasal migration of teeth or their roots. About one half of rhinitis cases in the dog are bilateral. The disease occurs mainly in higher age categories and clinically presents as epistaxis, epiphora, and facial deformities of the head. The discharge, that is initially pellucid, becomes purulent and bloody and is apparent in both nostrils. Traumatisation, ulceration and depigmentation of external nostrils may be observed. The nasal cavity is destroyed and distorted in advanced cases. Accompanying clinical signs include painful mouth opening, exophthalmus, and neurological disorders. Patients are snorting, shaking their head and trying to get rid of the mucus by rubbing their head against objects. Nostrils often become obstructed by crusts of dry exudates and the macerated skin around the eyes is bleeding. Chronic rhinitis accompanied by remittent epistaxis may be a sign of allergic reactions (Forbes Lent and Hawkins 1992). Body weight loss, lethargy and inapetence are the signs of general disease in the cat (mycotic infections, neoplasia). Aggressive lytic processes accompanying neoplasia and polyps may damage nasal conchae and bones and cause deformities of planum nasale. Obstruction to the respiratory tract causes snorting, intensity and frequency of which depends on the kind of the discharge. Neurological signs in cats include depression, derangement of visual orientation, ataxia, paresis and paralysis or even convulsions. Ocular affections manifest as $n$. opticus inflammation, granulomatous chorioretinitis, retinal detachment, uveitis anterior.

It was the aim of our project to work out a system of intravital differential diagnostics of upper respiratory tract diseases, in particular of the nasal cavity in the dog.

\section{Materials and Methods}

Patients

The study took place at the Small Animal Clinic of the Faculty of Veterinary Medicine of the Veterinary and Pharmaceutical University Brno. In all, 40 patients referred to our clinic for the purpose of performing a specialised rhinoscopy examination from co-operating clinics from around the Czech Republic were included in this study. Tab. 1 presents a survey of patient characteristics. 
Table 1

Basic characteristics of patients suffering from chronic rhinitis $(n=40)$

\begin{tabular}{|c|c|c|c|c|c|}
\hline Dogs & $\mathrm{N}$ & $\begin{array}{c}\text { Age interval } \\
\text { (years) }\end{array}$ & $\begin{array}{c}\text { Duration of } \\
\text { rhinitis (months) }\end{array}$ & $\begin{array}{c}\text { Unilateral } \\
\text { process }(\%)\end{array}$ & $\begin{array}{c}\text { Type } \\
\text { of discharge }\end{array}$ \\
\hline $\begin{array}{l}\text { German } \\
\text { Shepherd Dog }\end{array}$ & 10 & $0 ., 8-9 ., 5$ & $2-6$ & 70 & $\begin{array}{c}\text { clear, } \\
\text { mucopurulent, } \\
\text { blood tinged }\end{array}$ \\
\hline Dachshund & 4 & $3.5-12.5$ & $1-3$ & 75 & $\begin{array}{c}\text { clear, } \\
\text { mucopurulent }\end{array}$ \\
\hline Golden Retriever & 3 & $1-5$ & $2-3$ & 66 & mucopurulent \\
\hline Yorkshire Terrier & 3 & $1-10$ & $3-4$ & 33 & clear \\
\hline Boxer & 2 & $3-5$ & $1-2$ & 100 & $\begin{array}{l}\text { clear, blood } \\
\text { tinged }\end{array}$ \\
\hline Pomeranian & 2 & $1-9$ & $2-4$ & 50 & mucopurulent \\
\hline Poodle & 2 & $3.5-10$ & $2-5$ & 100 & mucopurulent \\
\hline Doberman & 2 & $1.5-8$ & $3-7$ & - & blood tinged \\
\hline Basset & 2 & $3.8-5$ & $2-4$ & - & mucopurulent \\
\hline Schnauzer & 1 & 5 & 3 & - & blood tinged \\
\hline German Pointer & 1 & 3 & 2 & 100 & clear \\
\hline English Setter & 1 & 8 & 3 & - & clear \\
\hline Slovak Sheepdog & 1 & 3 & 3 & 100 & mucopurulent \\
\hline Briard & 1 & 6 & 2 & 100 & clear \\
\hline Scottish Terrier & 1 & 4 & 4 & - & mucopurulent \\
\hline Collie & 1 & 10 & 3 & 100 & mucopurulent \\
\hline Caucasian Sheepdog & 1 & 8 & 2 & 100 & mucopurulent \\
\hline Belgian Sheepdog & 1 & 5 & 4 & - & mucopurulent \\
\hline Pitbull Terrier & 1 & 2 & 3 & 100 & clear \\
\hline
\end{tabular}

Clinical patient examination

The first step consisted of a thorough anamnestic record taking (age of the animal at the time of first clinical signs, duration of the disease, nature of the discharge, associations with the environmental factors and feed intake, health status of other animals kept, vaccinations, diagnostic health tests). Such signs as the current quantity and quality of the discharge, deformities of nostrils and facial parts of the head, head carriage, ocular discharge, maxillary teeth parodontium status, palatal and jaw cleft occurrence were evaluated.

\section{Anaesthesia}

Patients were induced to analgosedation using a combination of medetomidine (Domitor, Pfizer, USA) and butorphanol (Beforal, Léčiva a.s., Prague) in order to obtain high quality radiographs of the nasal cavity. Sampling for the cytological and histological examination was performed in patients under general anaesthesia induced by propofol (Diprivan, Zeneca Limited, U.K.) and kept by inhalation. An endotracheal tube was passed and the patients were positioned in sternal recumbency. Either halothane (Narcotan liq., Léčiva, a.s., Prague) or Isoflurane (Forane, Abbott) was used for the inhalation anaesthesia. Inhalation apparatus (Anesco, USA) was employed for 
this purpose. After specimen sampling and the inhalation anaesthesia the patients were administered the antagonist of medetomidine, i.e., atipamezole (Antisedan, Pfizer).

Radiography

At the Department of Visualisation Methods of the Small Animal Clinic there were performed radiographic examinations of the nasal and oral cavity of patients using following projections: head laterolateral (1-L), head with closed jaws ventrodorsal (V-D), nasal cavity dorsoventral with open mouth, sinus frontalis rostrooccipital, in indicated cases (stomatological indications) oblique maxillar projection into the open oral cavity.

Endoscopy (rhinoscopy)

A rigid endoscope (Hopkins, diameter $2.7 \mathrm{~mm}, 18 \mathrm{~cm}$, Karl Storz, Tuttlingen) was used to thoroughly examine the nasal cavity in its whole extent. Tissue specimens from areas of damage to the musosa and inner structure of the nasal cavity were sampled using biopsy forceps (67161 Z, Karl Storz, Tuttlingen) under endoscopic guidance. Several samples were always taken ( 2 to 3 on average). One part of samples taken was used to make impression smears for cytological evaluation. The other part was preserved in $10 \%$ neutral buffered formalin for histological examination.

Prevention of iatrogenic injury to the patient

After sampling patients were administered broad-spectrum antibiotics (amoxycillin, enrofloxacin or cephalosporins as needed and in relation to the health status of the patient). Cases of profuse bleeding were managed by nasal cavity lavage using normal saline followed by suctioning.

Cytological examination of biopsies

Impression smears of tissues obtained during the rhinoscopy nasal cavity examination were stained according to Romanowski a) May-Grünwald - Giemsa b) Haemacolor (Merck) and using the Gram's stain. Another staining was aimed at the identification of pathogens (fungi) using methylene blue (new methylene blue method) and PAS reaction. Cytological preparations were interpreted in the Laboratory of Cytology of the Small Animal Clinic. Samples were evaluated using the magnification of 100 to 1000 and an Olympus BX-40 microscope equipped for photo-documentation by a digital camera Olympus $2000 \mathrm{Z}$.

Histological examination of samples

Biopsy specimens for the histological examination were preserved in $10 \%$ neutral buffered formalin for 12 to $24 \mathrm{~h}$ and processed in a standard paraffin technique. Tissue sections of 4-6 $\mu \mathrm{m}$ were stained using hematoxylineosin. Differentiation of inflammatory and neoplastic lesions, determination of individual types of inflammation, classification of neoplasia into mesenchymal, epithelial and round-cellular tumours, and preliminary diagnosis of bacterial, parasitic and fungal diseases were performed in a specialised laboratory in the small Animal Clinic.

Determination of presence of infectious rhinitis causative agents

Under the guidance of a rhinoscope, deep swabs from affected areas were taken for the bacteriological and mycological cultivation to determine the pathogens and appropriate antibiotics (antimycotics). Commercially available transport media (Copan, Italy) were employed to provide the specialised laboratories (the Faculty of Veterinary Medicine of the Veterinary and Pharmaceutical University Brno, the State Veterinary Institute, Palackého 174, Brno) with the samples. Routine methods of these laboratories were used to determine the causative agents of rhinitis and their sensitivity to antibiotics and antimycotics.

\section{Results}

Evaluating the radiographs, we concentrated on disclosing asymmetry of the left and right side and osteolytic processes. These changes, however, may accompany both the chronic inflammation and neoplastic processes, thus, they are not by themselves specific and sufficient for the differential diagnosis. Frontal sinuses were best visualised using lateral and rostrooccipital projections. Radiographic visualisation of frontal sinuses and nasal cavity determined the extent of the process, i.e., damage to bones and cartilage, obliteration of respiratory airways. Comparing radiographs of patients affected either by chronic infectious rhinitis or neoplasia, we found in both groups relatively often marked and advanced changes in the structure if the internal architecture of the nasal cavity (aggressive lesions). In both groups of patients we observed distortions and septum nasale lysis and even facial area changes. Unilateral destruction of turbinates prevailed in patients with lymphosarcoma, as well as unilateral damage to lateral bone parts of the nasal cavity and teeth loss. In dogs we paid attention to the loss of a fine net of trabeculae, generally considered as a characteristic sign of intranasal 
neoplasia. Fungi caused increased radiolucency in the rostral part of nostrils, bone lysis, increased radiodensity in the caudal part of the nasal cavity and in the area of the frontal sinus.

Endoscopy of the nasal cavity revealed in most cases of chronic rhinitis mucosal congestion and presence of mucus. In dependence on the extent of damage to the internal structure of the nose (distortions of conchae, neoplastic growths, bacterial and mycotic granulomas) we observed limitations to the patency of respiratory airways and decreased manipulation space for the examination. Taking high care, it was possible to enter even the caudal parts of the nasal cavity, i.e., beyond the level of the medial eye canthus. In chronic rhinitis cases of bacterial origin we most frequently observed small lacunae of purulent exudate or purulent mucus obstructing the space between individual conchae. In several cases of mycotic rhinitis caused by the presence of Aspergilllus genus we observed typical pale plaques on the mucosa. Foreign bodies, particularly awns and parts of the grass spike, were mechanically removed using endoscopic forceps. Granulomas had a tendency to bleeding. Serious bleeding, nevertheless, was not encountered during examination of patients and sampling of tissues. Bleeding stopped mostly within 30 to 60 minutes from several specimens taking.

Cytological examination of biopsies

Results of cytological and histological examinations are presented as figures and summarised in Table 2.

Table 2

Results of cytological and histological examinations of the nasal cavity of patients suffering from chronic rhinitis $(n=40)$

\begin{tabular}{|c|c|c|c|c|c|}
\hline \multirow{3}{*}{$\begin{array}{l}\text { Dogs } \\
(n=40)\end{array}$} & \multicolumn{2}{|c|}{ Inflammatory process } & \multirow{2}{*}{$\begin{array}{l}\text { Foreign } \\
\text { bodies }\end{array}$} & \multicolumn{2}{|c|}{ Neoplastic process } \\
\hline & Bacterial & Mycotic & & Malignant & Benign \\
\hline & 16 & 7 & 8 & 7 & 2 \\
\hline
\end{tabular}

Determinations of causative agents of infectious rhinitis

Results of bacteriological and mycological examinations are presented in Table 3.

Table 3

Results of bacterial and mycotic cultivation of biopsies from the nasal cavity of dogs suffering from chronic rhinitis $(n=40)$

\begin{tabular}{|l|l|c|l|}
\hline \multirow{4}{*}{ Group } & Causative agents & Number of cases & Comments \\
\hline \multirow{5}{*}{ bacteria } & Staphylococcus intermedius & 7 & \\
\cline { 2 - 4 } & Staphylococcus aureus & 1 & \\
\cline { 2 - 4 } & Streptococcus canis & 3 & \\
\cline { 2 - 4 } & Pasteurella canis & 3 & primary neoplasia \\
\cline { 2 - 4 } & Pasteurella multocida & 1 & rhinitis, tracheitis, bronchitis \\
\cline { 2 - 4 } & Pseudomonas aeruginosa & 1 & foreign body \\
\cline { 2 - 4 } & Brevundimonas diminuta & 1 & neoplasia \\
\cline { 2 - 4 } & Moraxella catharalis & 1 & \\
\hline \multirow{5}{*}{ fungi } & Aspergillus niger & 3 & foreign body \\
\cline { 2 - 4 } & Aspergillus fumigatus & 1 & foreign body \\
\cline { 2 - 4 } & Aspergillus ustus & 1 & \\
\cline { 2 - 4 } & Rhizopus stolonifer & & \\
\hline
\end{tabular}




\section{Discussion}

Most chronic disease of the nasal cavity are classified as an inflammation or neoplasia. The differentiation is mostly not possible only on the basis of clinical signs, because they are to a greater extent non-specific (Norsworthy 1995a; Nors w orthy 1995b; Thé on et al. 1995; Thé on et al. 1996). Historical data on the case are also non-specific, for common presenting signs of complications in the nasal cavity include nasal discharge and snorting. Rhinoscopy (Caniatti et al., 1998ab; Forbes Lent and Hawkins 1992; McCullough et al. 1998; Ogilvie and LaRue 1992; Théon et al. 1995) is a demanding, and yet diagnostically valuable, method of visualisation. Rhinoscopy makes it possible to directly inspect the status of the mucosa and the contents of the nasal cavity. It is excellent for finding intranasal parasites, foreign bodies, oronasal fistulas, extensive lesions, erosions and mycotic plaques. Rhinoscopy as a visualisation method may help in crucial decisions concerning the diagnostics of rhinitis only in a limited number of specific complications (foreign bodies, advanced neoplasia, and mycotic infections). Credibility of such decisions considerably depends on the examiner's experience. Cytological and histological examination of biopsies is an essential diagnostic procedure. It is clear that there are certainly some limitations to the use of a rigid rhinoscope. It is particularly the size of the patient and the status of the mucosa in the nasal cavity. In small dogs and cats rhinoscopy may be relatively difficult due to narrow nasal airways and frequent bleeding (Willard and Radlinsky 1999). That is why some authors prefer the use of flexible endoscopes which are passed up to the choanae retropharyngeally through the mouth (Willard and Radlinsky 1999). This method of examination was also introduced in our clinic and we now combine examination of rostral and middle parts of the nasal cavity by a rigid endoscope and of caudal parts using a flexible bronchoscope (Olympus). Results obtained by this combined technique are not included in this paper. The method is destined mainly for dogs, because the use of a rigid rhinoscope is limited only to larger animals having broader entrance into the nasal cavity and, likewise, the manipulation possibilities of a flexible bronchoscope in cats are restricted. On the other hand, this procedure is very effective because in the caudal part of the nasal cavity near choanae there are relatively frequently found neoplasia (Willard and Radlinsky 1999). Numerous methods for tissue sampling from the nasal cavity such as lavage, swabbing, scraping, fine-needle aspiration biopsy and impression smears of tissue samples before their histological examination (Caniatti et al. 1998ab; Cowell et al. 1999; Flatland et al. 1996; Gas kell and Gaskell 1997; Meyer 1987) were described. There are other methods including sampling using a catheter and biopsy specimen obtaining under the guidance of a rhinoscope. Methods of impression smears and fine-needle aspiration biopsy provide very consistent results in cases of advanced neoplastic processes. The brush technique is based on the use of a small nylon brush which is inserted in the nasal cavity under endoscopic guidance. It is then moved back and forth and rotated over the nasal mucosa. The harvested tissue sample is then gently smeared of the glass slides and stained according to May-Grünwald and Giemsa. Using this method it is possible to achieve nearly 90\% accuracy of differentiation between inflammatory and neoplastic processes in the nasal cavity of cats (results checked by histology). Positive results were obtained with $94.1 \%$ accuracy and the negative ones amounted to $83.3 \%$ accuracy (Caniatti et al. 1998a). High quality samples for the histology may be obtained during operative procedures in the nasal cavity (rhinotomy, turbinectomy). These procedures, however, are in some patients with regard to their age and health status contraindicated, may cause chronic postoperative complications and are particularly very expensive. Complications of operative examination procedures include dehiscence of the macerated wound, subcutaneous emphysema, injury to the brain, blood and exudate aspiration, respiratory difficulties and in exceptional cases even death of the patient. Hazards 
include profuse bleeding in patients suffering from coagulopathies (e.g., DIC) and complications associated with anaesthesia in dogs and cats with functional disorders of the circulatory and respiratory apparatus and the liver.

Iatrogenic bleeding is prevented by careful and considerate handling with the endoscope. There were no serious complications due to bleeding in our practice. Bleeding stopped mostly within 30 to 60 minutes after rhinoscopy. Diagnostics of chronic rhinitis cases always requires concurrent examination of the oral cavity and teeth (Marretta 1992). When there is an inflammation in the inner structure of the tooth, e.g., the pulp, it is called endodontitis. As a sequel there may form a periapical granuloma draining to the nasal cavity (C1) or recessus maxillaris (P4, M1). This complication is most frequently encountered in dogs and cats following trauma associated with tooth fracture. Severe periodontitis may result in damage of the alveolar wall and transmission of the infection to the nasal cavity. This type of oronasal fistula is frequent on the palatal side of maxillary canines. Intranasal presence of the tooth is rarely found. It may happen when the bony septum gets damaged and there is high preassure on the tooth (caused by trauma in the oral cavity, e.g., during fights). Foreign bodies in the nasal cavity are diagnosed directly by rhinoscopy or histologically by examination of encapsulated bodies under the mucosal surface. It is especially a foreign body staying in the nasal cavity for a longer time that becomes covered by the granulation tissue, fibrin and sometimes fungal colonies. Most frequent foreign bodies are awns, grass spikes and thorny twigs that firmly stuck to the mucosa and cannot be expelled by snorting (Wolf 1992).

Normal cytological finding of the nasal cavity examination in healthy animals may contain numerous microorganisms and epithelial cells. Epithelial cells differ in dependence to the area of origin and depth of sampling (Cowell et al. 1999; Meyer 1987; Smith 1995). In the area of oropharynx and external nares there are non-keratinised, desquamated cells which have often bacteria adhered to their surface. Deeper in the nose the number of cubic ciliary cells increases at the expense of desquamated cells. In the mucosa, there are sometimes cubic cells containing metachromatic granules. In deeper layers there are basal epithelial cells. They are smaller than the cubic cells, have a rounded shape and dark blue cytoplasm. Leukocytes and erythrocytes originating from bleeding during tissue sampling are frequently found as contamination. In such cases the ratio of leukocytes to erythrocytes is 1:500 to $1: 1000$. Nasal lavage samples from healthy animals contain only a small amount of neutrophils and macrophages. When there is an infection in the nasal cavity, the inflammatory exudate contains various numbers of neutrophils, macrophages, lymphocytes and plasmatic cells. Rhinitis is then classified as purulent (most cell are neutrophils), granulomatous (monocytes, macrophages and lymphocytes prevail), pyogranulomatous (mixed cellular populations) or eosinophilic. Neutrophils usually dominate the exudate in bacterial, viral, and some fungal infections.

An active bacterial infection is characterised by the occurrence of engulfed bacteria inside the neutrophil. It is also the bacterial uniformity that indicates the probability of an active bacterial infection (Cowell et al. 1999; Meyer 1987). The presence of various bacteria kinds and their adherence to desquamated cells indicates contamination during sampling. Secondary bacterial infections accompany viral infections, neoplastic processes, traumatic injuries or irritation of the nasal mucosa. Our patients were sampled for bacteriological cultivation using endoscopic forceps under the guidance of a rhinoscope. Areas of marked changes in the structure of the mucosa were selected for sampling. Results of bacteriology were compared to those ones of cytology and histology. In all, 40 such combined examinations resulted in the confirmation of 16 cases (40\%) of bacterial rhinitis without the accompanying fungal infection. Staphylococcus intermedius, Streptococcus canis and Pasteurella canis were most frequently diagnosed. Other bacterial agents such as 
Staphylococcus aureus, Pasteurella multocida, Moraxella catharalis, Pseudomonas aeruginosa, Brevundimonas diminuta were found only as an exception.

Mycotic infections in the nasal cavity are diagnosed on the basis of swab cultures, cytology of nasal cavity content and mucosa, as well as evaluations of radiography of the nostril structure. Aspergillosis manifests by the presence of bran-like plaques (up to $75 \%$ of cases) on the mucosa that is frequently affected in an extensive way. Aspergillosis in patients may also be confirmed serologically. The diagnosis of cryptococcosis is based on cytology or histology used to identify the agent in the specimen sampled from affected nostrils. The cytology of mycotic infections looks like hyphae making dense clusters together with cells and amorphous material. Hyphae do not stain well by common cytological stains and, therefore, look like lucid filamentous structures surrounded by cells. It is, therefore, necessary to use some special methods (e.g. PAS reaction) directly staining the fungi. In our group of patients we found 7 cases of chronic mycotic rhinitis (17.5\%); three cases being a combination of neoplasia and secondary mycotic infections. Aspergillus niger, A. fumigatus, A. ustus and Rhizopus stolonifer were the mycotic agents found. The identification of the Aspergillus genus amounted to more than $85 \%$ of all cases. Rhizopus stolonifer was identified only in one case and was regarded as a contaminant. Fungi of the Aspergillus genus were identified as serious causes of chronic rhinitis only on the basis of independent histological verification. The presence of fungi was in 3 cases only secondary to the contamination of neoplasia and in two cases the fungal infection developed as a complication of a foreign body in the nasal cavity.

Allergies in the nasal cavity are accompanied by eosinophilic infiltration. There are even other possible causes of eosinophilic infiltration such as fungi, parasites, bacteria or neoplasia. No case of allergic rhinitis was diagnosed in our group of patients.

Intranasal neoplasia are expected when the cytological sample falls within basic criteria of malignancy: high numbers of cells, irregular chromatin structure, increased ratio of the nucleus to cytoplasm, mitotic index (Cowell et al. 1999; Meyer 1987). Anamnestic data, clinical findings in the patient and results of radiography are also taken into consideration. The cytological diagnostics of neoplasia is made difficult by secondary hyperplastic and dysplastic changes of the epithelial tissue due to the inflammation and necrosis. The cytological samples removed from neoplastic lesions thus may contain higher quantities of erythrocytes, inflammatory cells, bacteria and amorphous necrotic matter. Specimens from fine-needle aspiration or endoscopic biopsy are more diagnostically valuable than cytological samples obtained during nasal lavage. There is usually enough exfoliation in carcinomas. Less differentiated carcinomas tend to exfoliate in a separate way. The cells are oval to round, have different nucleus to cytoplasm ratio and increased numbers of nucleoli. These criteria of malignancy are less expressed in differentiated tumours and it is difficult to cytologically differentiate benign tumours from hyperplastic epithelial cells (Ogilvie and LaRue 1992; Théon et al. 1995; Théon et al. 1996). The cells may form acinar structures. The cellular population in adenocarcinomas may be accompanied by mucous matter that looks like amorphous or linear eosinophilic matter. Cells of osteosarcoma or chondrosarcoma may contain larger areas of basophilic cytoplasm with eosinophilic granules. Tumours of this group, chondrosarcomas in particular, produce high quantity of amorphous eosinophilic matter which in some instances may mask cellular details. Regarding the differential diagnostics it is sometimes necessary to distinguish hyperplasia and tomours of the connective tissue using histology. It is also the precise typing of mesenchymal tumours (osteosarcoma, chondrosarcoma, fibrosarcoma and others) that requres the histological examination. As far as round cellular tumours are concerned, there occur lymphosarcomas, mastocytomas and transmissible venereal tumours in the nasal cavity. As a rule, these tumours show high cellularity and their cells exfoliate in a separate 
way. The cells have a round shape and clear cytoplasmic margins. Osteosarcoma, lymphosarcoma and adenocarcinoma were the most frequent neoplasia in the nasal cavity in our group of patients. Malignant tumours prevailed (77.8\%). These cases were thoroughly discussed with the owner and because of acceleration of the neoplastic process development due to the biopsy, the patients were euthanatised within a 1 to 1.5 month period. Radiotherapy was not possible because of technical reasons. Use of cytostatics was unreasonable in many cases and financial costs rather complicated the situation.

\section{Nemoci dutiny nosní psa. Etiologie, symptomatologie, diagnostika}

Systém intravitální diferenciální diagnostiky nemocí dutiny nosní byl ověřen u 40 psů. Pro zhotovení RTG snímků dutiny nosní byli pacienti uvedeni do analgosedace kombinací medetomidinu s butorphanolem. Pro odběry vzorků na cytologické a histologické vyšetření byli pacienti připraveni $\mathrm{v}$ celkové anestezii propofolem a následnou inhalační anestezií halotanem nebo isofluranem. K podrobnému vyšetření dutiny nosní byl použit rigidní endoskop (Hopkins, průměr 2,7 mm, $18 \mathrm{~cm}$ ). Vzorky tkání z míst poškození sliznice a narušené vnitřní architektury nosní dutiny byly pod kontrolou endoskopu odebrány bioptickými nůžkami. Část vzorků tkání byla určena ke zhotovení otiskových preparátů pro cytologické vyšetření; druhá část $\mathrm{k}$ histologickému zpracování. U pacientů trpících chronickými infekčními rinitidami a neoplaziemi jsme zjištovali u obou skupin výrazné a pokročilé změny v utváření vnitřní architektury dutiny nosní (agresivní léze). V několika případech jsme u mykotických rinitid vyvolaných přítomností plísní rodu Aspergillus pozorovali na sliznici typické světlé plaky. Cizí tělesa, především osiny a části klasu byla mechanicky odstraněna pomocí endoskopických nůžek. Granulomy vykazovaly tendenci silného krvácení. Závažnější krvácení se $\mathrm{v}$ průběhu vyšetřování nevyskytlo. Výsledky bakteriologické kultivace byly konfrontovány s výsledky cytologického a histologického vyšetření. Ze 40 takovýchto kombinovaných vyšetření byly v 16 případech (40\%) potvrzeny bakteriální rinitidy bez přítomnosti plísní a změn odpovídajících neoplastickému procesu. Nejčastěji byly prokázány Staphylococcus intermedius, Streptococcus canis a Pasteurella canis. Další bakteriální mikroorganismy byly prokazovány pouze výjimečně. Mykotické infekce byly diagnostikovány v 7 případech chronických mykotických rinitid $(17,5 \%)$. Rod Apergillus představoval více než $85 \%$ všech záchytů mykotických agens. Ve 2 př́ípadech představovaly plísně komplikaci cizího tělesa $v$ dutině nosní. Ve vyšetřovaném souboru pacientů jsme nepotvrdili případy alergické rinitidy. Převládaly maligní nádory $(77,8 \%$ \%). Častými neoplaziemi v dutině nosní psů byly osteosarkom, lymfosarkom a adenokarcinom.

\section{Acknowledgements}

This paper originated as part of the Research Project of Ministry of Education of CR (grant No. 161700002). The authors are grateful to Alena Kocichová, Dagmar Karešová and Tomáš Výmola for their technical assistance during the anesthesia of patients and biological material sampling. Thanks also belong to Mrs Vera Vyhlídalová who processed histological preparations. The first author (Z.K.) would like to thank Dr. R. Hirt (Veterinary University Vienna) for his valuable advise and consultation of video records of the endoscopic examination of respiratory airways in the dog.

\section{References}

CANIATTI, M., ROCCABIANCA, P., GHISLENI, G, MORTELLARO, C.M., ROMUSSI, S., MANDELLI, G. 1998a: Evaluation of brush cytology in the diagnosis of chronic intranasal disease in cats. J Small Anim Pract. 39: 73-77

CANIATTI, M., ROCCABIANCA, P., SCANZIANI, E., FINAZZI, M., MORTELLARO, C.M., ROMUSSI, S., MANDELLI, G. 1998b: Nasal rhinosporidiosis in dogs: four cases from Europe and a review of the literature. Vet. Rec. 142: 334-338

COWELL, R.L., TYLER, R.D., MEINKOTH, J.H. 1999: Diagnostic Cytology and Hematology of the Dog and Cat., Mosby, St. Louis, pp. 52-58 
FLATLAND, B., GREENE, R. T., LAPPIN, M. R. 1996: Clinical and serologic evaluation of cats with cryptococcosis. Amer. J. Vet. Res. 209: 1110-1113

FORBES LENT, S. E., HAWKINS, E. C. 1992: Evaluation of rhinoscopy and rhinoscopy-assisted mucosal biopsy in diagnosis of nasal disease in dogs: 119 cases (1985-1989). J Amer. Vet. Med. Assoc. 201: 1425-1429

GALLOWAY, P.E., KYLES, A., HENDERSON, J. P. 1997: Nasal polyps in a cat. J. Small Anim. Pract. 38: 8-80 GASKELL, C. J., GASKELL, R. M. 1997: Chronic nasal and oral diseases in cats. Vet. Quart. 19, Suppl 1, 8-9

MARRETTA, S.M. 1992: Chronic rhinitis and dental disease. Vet. Clin. North. Amer. 22: 1101-1117

McCUlloUGH, S. M., KIERNAN, B. C., GRODSKY, B. S. 1998: Endoscopically placed tubes for administration of enilconazole for treatment of nasal aspergillosis in dogs. J. Amer. Vet. Med. Assoc. 212: 6769

MEYER, J. B. 1987: The management of cytology specimens. Comp. Cont. Educ. Pract. Vet. 9:10-16

NORSWORTHY, G. 1995a: Finding the cause of chronic nasal discharge in cats. Vet. Med. 90: 1038-1046

NORSWORTHY, G.1995b: Treating chronic nasal discharge in cats. Vet. Med. 90: 1048-1054

OęBRIEN, R. T., EVANS, S. M., WORTMAN, J. A., HENDRICK, M. J. 1996: Radiographic findings in cats with intranasal neoplasia or chronic rhinitis: 29 cases (1982-1988). J. Amer. Vet. Med. Assoc. 208: 385-389

OGILVIE, G. K., LaRUE, S. 1992: Canine and feline nasal and paranasal sinus tumors. Vet. Clin. North. Amer. 22: $1133-1144$

SMITH, M. M. 1995: Oral and Salivary Gland Disorders. In: Ettinger, S. J. Textbook of Veterinary Internal Medicine. 4. ed. Saunders, Philadelphia, 1090 p.

THÉON, A. P., MADEWELL, B. R. SHEARN, V.I., MOULTON, J. E. 1995: Prognostic factors associated with radiotherapy of squamous cell carcinoma of the nasal plane in cats. J Amer. Vet. Med. Assoc. 206: 991-997

THÉON, A. P., Van VECHTEN, M. K., MADEWELL, B. R. 1996: Intratumoral administration of carboplatin for treatment of squamous cell carcinomas of the nasal plane in cats. Amer. J. Vet. Res. 57: 205-210

WOLF, A. M. 1992: Fungal diseases of the nasal cavity of the dog and cat. Vet. Clin. North.Amer. 22: 1119-1131

WILLARD, M. D., RADLINSKY M. A. 1999: Endoscopic examination of the choanae in dogs and cats: 118 cases $(1988$ - 1998). J. Amer. Vet. Med. Assoc. 215: 1301-1305 
Plate XIII

Knotek Z. et al.: Diseases... pp. 73-82

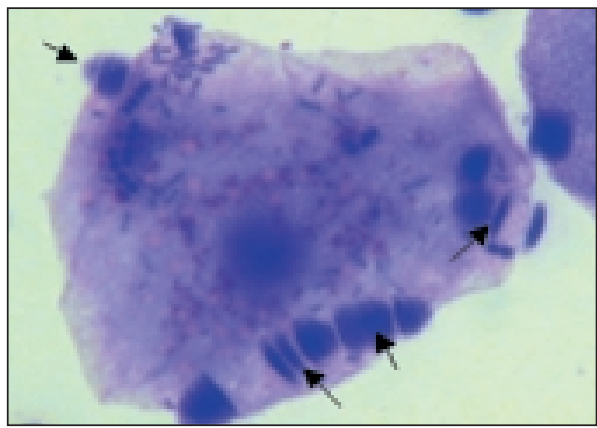

Fig. 1. Rods of Simonsiella spp. bacteria forming large clusters most frequently adhering to surface epithelial cells.

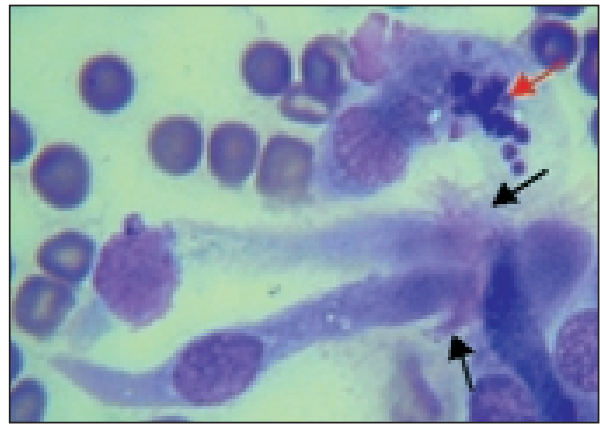

Fig. 3. Normal finding. The ciliary epithelium consists of elongated cells having the nucleus in their basal part and cilia in the apical part (cf. black arrow). The red arrow points at a cluster of granules that stain metachromatically in a secretory cell.

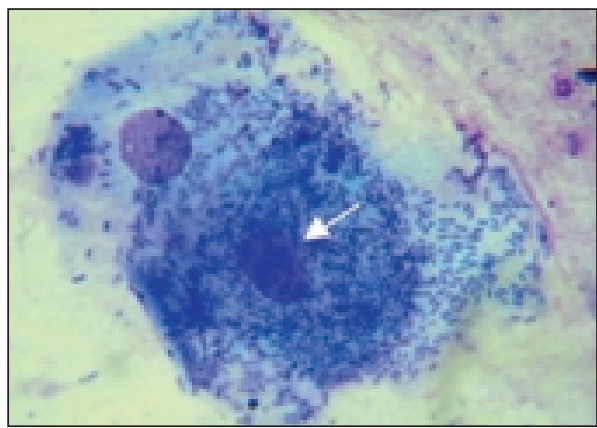

Fig. 2. Great quantity of bacteria (rods) to predominantly adhering to two flat epithelial cells. This finding was considered as contamination without active bacterial infection. The nucleus of one epithelial cell is completely covered by bacteria (see the arrow).

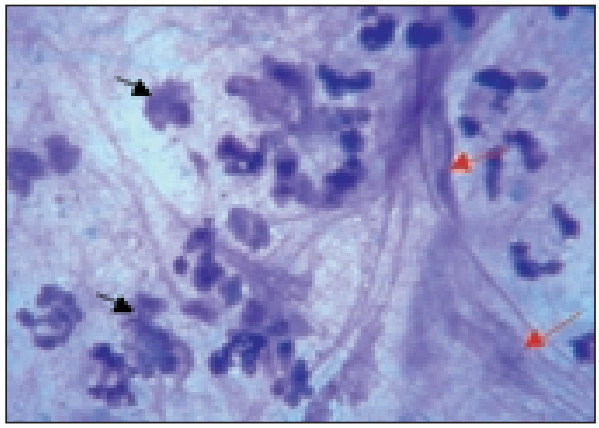

Fig. 4. Neutrophils dominate the cellular population of purulent inflammations. Bacterial toxins cause disintegration of neutrophils, the nuclei loss their segmentation and gain eosinophilia (black arrows). Chronic tissue irritation causes increased mucus secretion resulting in the formation of eosinophilic irregular linear structures (red arrows). 
Plate XIV

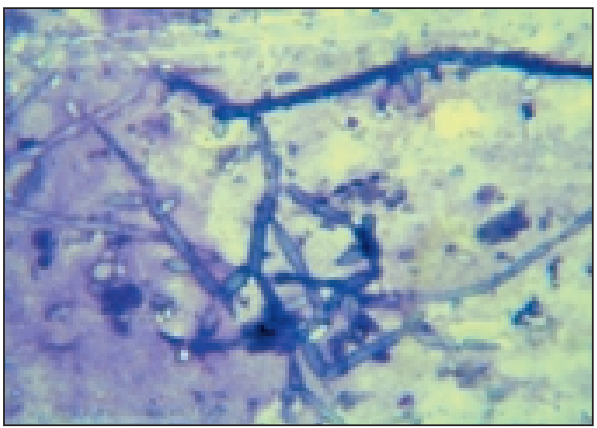

Fig. 5. Fungal hyphae in the cytological preparation look like branching filamentous structures with differing intensity of staining.

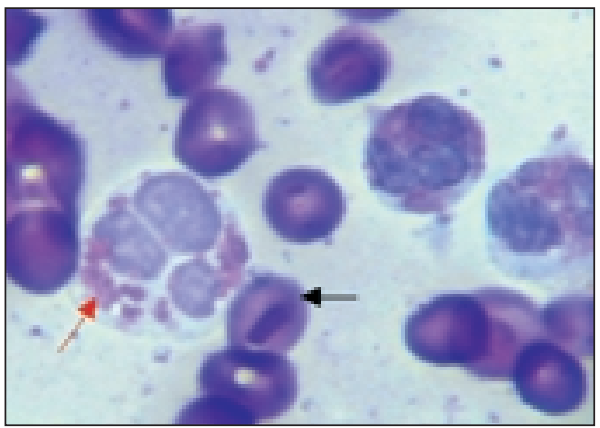

Fig. 6. Eosinophils. The red arrow points at eosinophilic granules, the black one at erythrocytes.

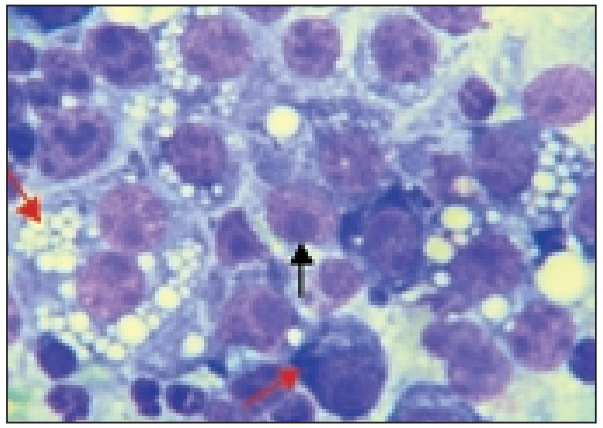

Fig. 7. Cells in the preparation show high pleomorphism, have increased numbers of nucleoli, some nuclei contain macronucleoli (black arrow). Cytoplasm of some cells is highly basophilic and vacuolated (red arrows). The cytological diagnosis of adenocarcinoma was confirmed histologically.

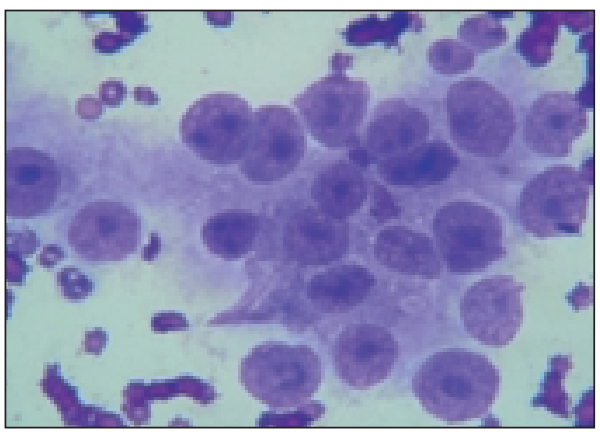

Fig. 8. Epithelial cells show some anisocytosis, anisokaryosis, one or two prominent nucleoli as in adenomas or dysplastic tissues. Concurrent occurrence of inflammatory infiltrates witness for dysplasia, it is, however, necessary to gain the final diagnosis using histology. It was adenoma that was diagnosed in this case. 
Plate XV

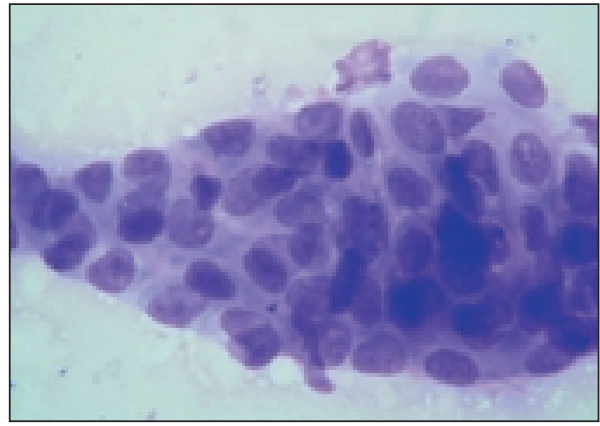

Fig. 9. The cellular population is similar to the cells of the previous picture. The cells in this case show dysplastic changes due to chronic irritation.

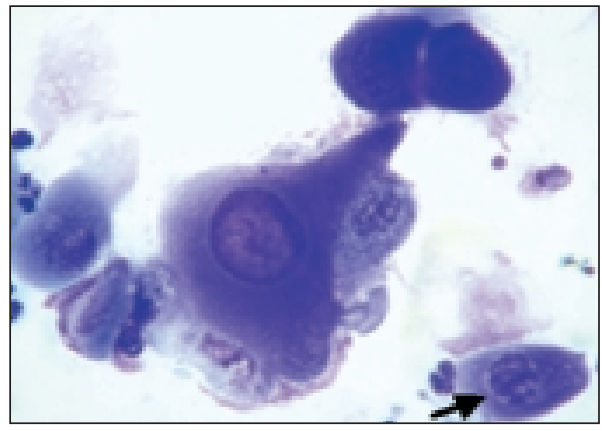

Fig. 10. In cases of squamous cell carcinoma there are nuclei still present in such cell that should already be cornified. Marked anisocytosis, anisokaryosis and basophilia witness for malignancy of the tumour. Other signs of malignancy include the occurrence of perinuclear halo and vacuolisation of nuclei (arrow).

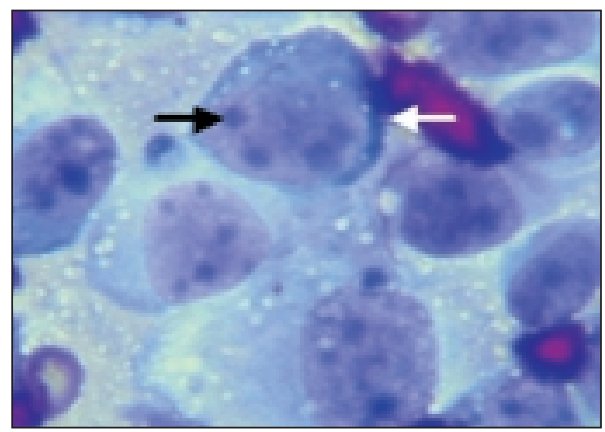

Fig. 12. Osteosarcoma. Cells of the tumour show marked signs of malignity: anisocytosis, anisokyryosis, basophilia of the cytoplasm (white arrow), high nucleolar/cytoplasmic ratio and 1 to 6 nucleoli (black arrow). The cells lost their characteristics of mesenchymal tissue.

one nucleolus at maximum witness for the benig character of the tumour. Cytoplasmic protuberantia in one or two directions from the nucleus (black arrows) are typical for tumours of mesenchymal origin. 
Plate XVI

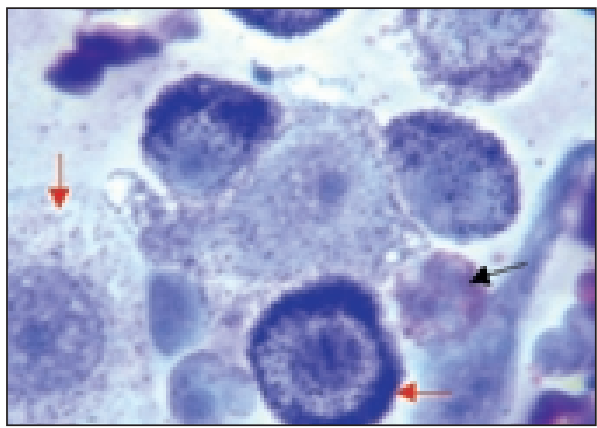

Fig. 13. Mastocytoma. The cellular population consists of mast cells which contain cytoplasmic granules (red arrows). There are regularly eosinophils present in this type of tumour (black arrow).

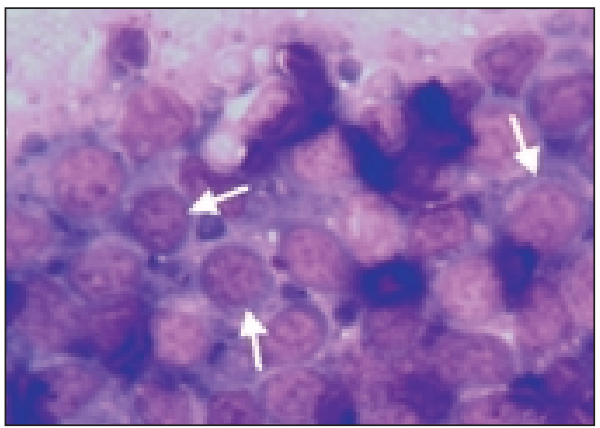

Fig. 14. Lymphosarcoma in a cat is formed by roundcellular infiltrates. The round nucleus has a narrow rim of basophilic cytoplasm (arrows)

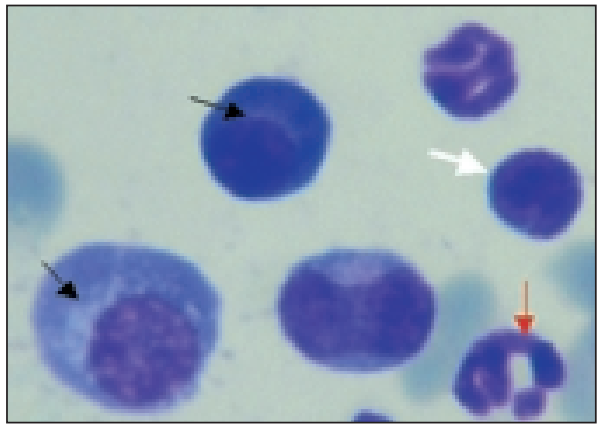

Fig. 15. The red arrow points at the segmented nucleus of a neutrophil, the white arrow shows a lymphocyte and black arrows point at a typical perinuclear halo of plasmatic cells. Increased numbers of plasmatic cells may witness for neoplasia as well as a reaction on antigenic stimulation of lymphatic tissue in the submucosa or lymphocytoplasmocytar rhinitis. 